\title{
Chemical Characterization of Airborne Particles Collected in an Underground Metro Station Platform in Delhi City
}

\author{
By Praveen Babu* \\ Mukesh Khare \\ Radha Goyal
}

\begin{abstract}
Transport systems in urban land spaces are shifting to underground due to the unavailability of space on the surface. Nowadays, the underground metro system has become an imperative mode of transport. Since people spend considerable time in underground metro stations (UMS), indoor air quality (IAQ) has become an important parameter of investigation. However, maintaining IAQ at UMS has become a major issue for developing countries. Hence, the assessment and management of IAQ in UMS is important for a healthier indoor environment. The present study includes an elemental composition of indoor/outdoor (I/O) particulate matter in a UMS in Delhi city, India during winter season. The study mainly focused on metals and carcinogenic elements. Out of 41 metals analyzed, the main contributors to the indoor pollution at the UMS platform and outdoor were Iron at a concentration of $24.54 \mu \mathrm{g} / \mathrm{cm} 2$ and 2.58 $\mu \mathrm{g} / \mathrm{cm} 2$, followed by Manganese $0.36 \mu \mathrm{g} / \mathrm{cm} 2$ and $0.08 \mu \mathrm{g} / \mathrm{cm} 2$, Copper $0.73 \mu \mathrm{g} / \mathrm{cm} 2$ and $0.15 \mu \mathrm{g} / \mathrm{cm} 2$, Calcium $12.77 \mu \mathrm{g} / \mathrm{cm} 2$ and $4.55 \mu \mathrm{g} / \mathrm{cm} 2$ and Silicon $34.70 \mu \mathrm{g} / \mathrm{cm} 2$ and $10.92 \mu \mathrm{g} / \mathrm{cm} 2$, respectively. Further, it has been found that indoor elemental concentrations are higher than that of outdoor environment concentrations. The results of this study will help identify the different sources from various activities within the UMS, in order to select suitable environmental management techniques to manage the IAQ in UMS better.
\end{abstract}

Keywords: Elemental compositions, Indoor air quality, Particulate matter, Underground metro station

\section{Introduction}

Most of the people spend their time indoors more than outdoors, either at residential, commercial, working environments or in transit and there is an increasing concern over the IAQ in different microenvironments and its effects on public health. The UMS have been considered as an important mode of transport in order to improve the quality of transport, relieve congestion, as well as to fill the gaps of insufficient public transport and the road surface capacity (Pfeiffer et al., 1996). It has a unique microenvironment because of their closed character, restricted ventilation, specific emission sources and complex indoor meteorology. The confined space in the underground metro

\footnotetext{
${ }^{*}$ Research Scholar, Indian Institute of Technology Delhi, India.

${ }^{\dagger}$ Professor, Indian Institute of Technology Delhi, India.

* Postdoctoral Fellow, Indian Institute of Technology Delhi, India.
} 
environment enhances the concentration of pollutants either by infiltration from outdoor or internal generation (Boudia et al., 2006; Chan et al., 2002; Kang et al., 2008). Delhi being a metropolitan city forces millions of people to choose the underground metro systems over other road transportation systems owing to its speed and convenience. The Delhi Metro Rail Corporation (DMRC) system carries approximately 2.5 million passengers daily (www.delhimetrorail.com). Since people spend a considerable amount of time in the underground metro system daily, the IAQ has become an important apprehension for the users in metro stations (Johansson and Johansson, 2003). The sources of the different indoor air pollutants within the UMS and its health effects on the metro users (i.e. both metro staffs and commuters) are of great concern.

Numerous scientific studies show that the airborne particle concentrations in UMS differ from street-level particulate matters (PM) with respect to its particulate morphology, concentration, size distribution, and its chemical compositions. Relative to street-level particles, subway particles are generally more angular in shape, larger in diameter, more abundant by mass, and contain higher levels of the metals found in steel (Sitzmann et al., 1999; Seaton et al., 2005; Lee et al., 2012). The metallic composition of PM found in UMS includes iron $(\mathrm{Fe})$, manganese $(\mathrm{Mn})$, chromium $(\mathrm{Cr})$, nickel $(\mathrm{Ni})$, and copper (Cu) (Aarnio et al., 2005; Chillrud et al., 2005; Colombi et al., 2013; Eom et al., 2013; Frampton et al., 1999; Kam et al., 2011; Li Guo et al., 2014; Lu Senlin et al., 2015; Ripanucci et al., 2006; Salma et al., 2007). It indicates that $\mathrm{PM}$ at UMS is generated through the friction of wheels and rails, brake wear, and the vaporization of metals due to sparking (Pfeiffer et al., 1996; Sitzmann et al., 1999). In New York City, the concentrations of $\mathrm{Fe}, \mathrm{Mn}$, and $\mathrm{Cr}$ in suspended particulate matter (SPM) have been found to be more than 100 times higher in the subway station than above the ground level (Chillrud et al., 2005). These subway particles have a greater capacity to induce Deoxyribonucleic acid (DNA) damage and oxidative stress in cultured lung cells than outdoor (street-level) particles due to their high reactivity (Karlsson et al., 2005; Seaton et al., 2005; Simge Taner et al., 2013). Further, Zhang et al. (2011) carried out scientific research on the magnetic characterization and geochemistry of dust particles in the Shanghai metro system. Their results shows that the magnetic properties of the particles were of scrap-iron and spherical magnetic particulates, and that there were higher levels of Fe and Mn, and lower levels of aluminium ( $\mathrm{Al}$ ) and titanium (Ti), in metro system dusts (Lu Senlin et al., 2015).

This is a novel study in the Delhi metro analyzing the chemical compositions of the respirable suspended particle (RSP) [viz., particles with diameter of 10 micrometers or less] collected at one of the selected UMS platform and outdoor environment in Delhi city, India, using a quantitative particle analysis based on Energy Dispersive X-Ray Fluorescence (EDXRF). 


\section{Materials and Methods}

Study Site

Delhi is a part of the Indo-Gangetic plains at an elevation ranging from 213 meters to 305 meters above the mean sea level and lies between latitudes $28^{\circ} 12^{\prime}$ to $28^{\circ} 63^{\prime} \mathrm{N}$ and longitudes $75^{\circ} 50^{\prime}$ to $77^{\circ} 23^{\prime} \mathrm{E}$ with a total area of $1484.46 \mathrm{~km} 2$ (Figure 1). The climate of Delhi is semi-arid and is mainly influenced by its inland position and prevalence of continental air all throughout the year (Mugica Alvarez et al., 2012).

Figure 1. Study Site Map

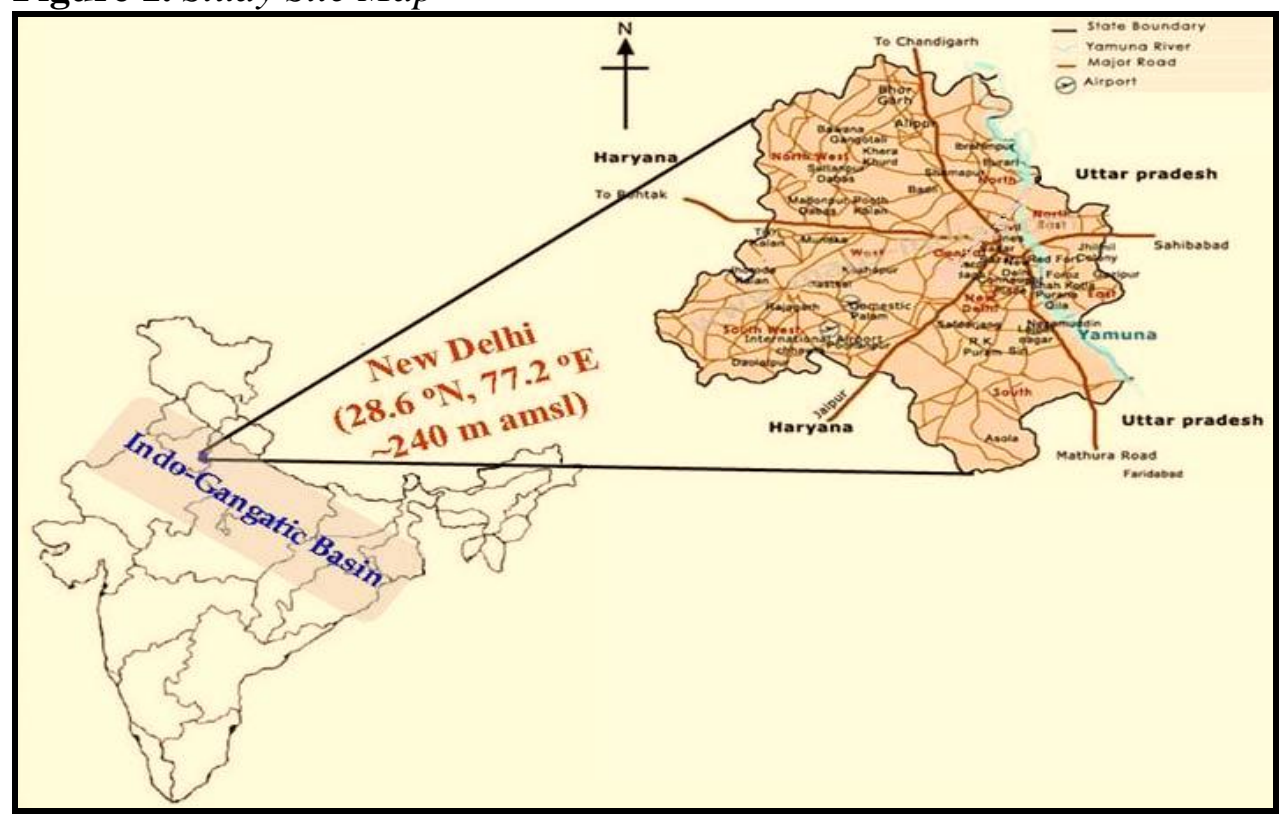

\section{Particle Collection}

We had selected one of the busiest UMS on the yellow line in the DMRC network as the number of commuters keeps increasing at a steady phase. Monitoring and collection of RSP was done simultaneously in the UMS platform and outdoor environment.

A measurement of RSP collected from indoor and outdoor environments was done at a $24 \mathrm{hrs}$ average monitoring frequency at a selected UMS during winter season (i.e. December, 2013 to February, 2014). For the monitoring of RSP, an environmental dust monitor [GRIMM, 1.107 model] was used and air flow was maintained at $1.2 \mathrm{~L} \mathrm{~min}^{-1}$. 
Figure 2. Monitoring Location in UMS

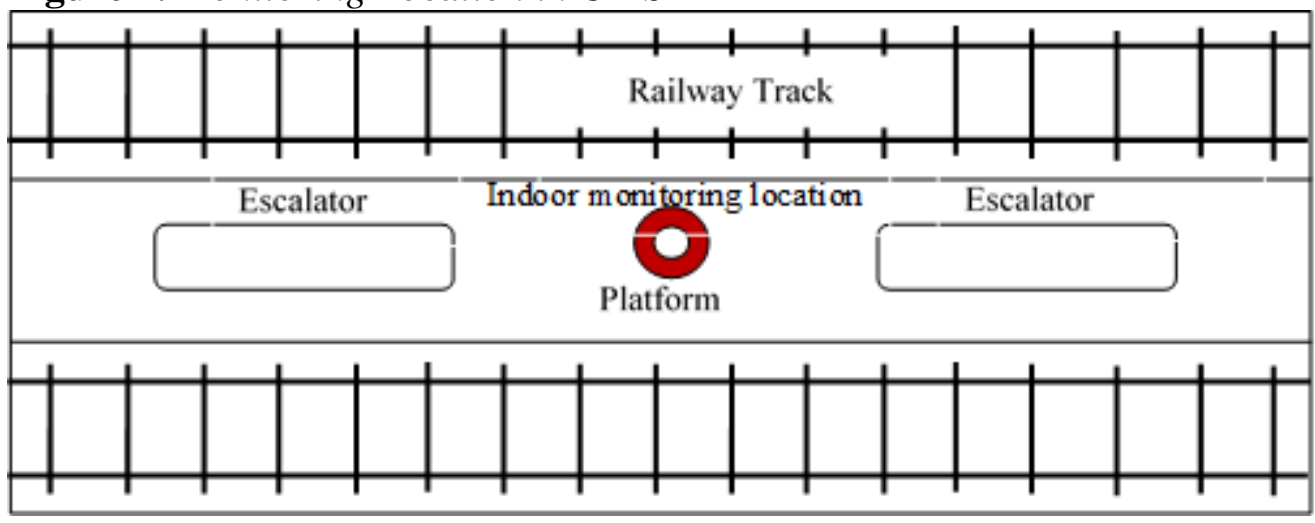

The monitoring equipment was kept at the middle of the UMS platform (Figure 2) inside the metro station. The monitoring device was kept on the rooftop of the building ( $\sim 12 \mathrm{~m}$ above ground level) for the measurement of the outdoor RSP. Particles were collected on $47 \mathrm{~mm}$ diameter polytetrafluoroethylene (PTFE) filters of pore size $1.2 \mu \mathrm{m}$.

\section{Analytical Method}

EDXRF spectrometry can be used for all elements (USEPA Method IO 3.3) (U.S. Environmental Protection Agency, 1999). This analysis technique is nondestructive and requires minimal sample preparation - the filter is inserted directly into the instrument for analysis (Perrino et al., 2011). In this study, a total of 41 elements were analyzed quantitatively by using XRF.

\section{Results and Discussion}

In this study, characterized metals are distributed into two categories i.e. trace $(\mathrm{Mn}, \mathrm{Cu}$ and $\mathrm{Zn})$ and carcinogenic $(\mathrm{Cr}, \mathrm{Ni}$ and $\mathrm{Cd})$. Trace elements were found to be dominant in comparison to carcinogenic metals influencing the indoor RSP collected in the UMS platform (i.e. $\mathrm{Zn}>\mathrm{Cu}>\mathrm{Mn}>\mathrm{Cd}>\mathrm{Cr}>\mathrm{Ni}$ ) (Table 1). 
Table 1. Indoor/Outdoor Metal Concentration in UMS

\begin{tabular}{|c|c|c|c|c|c|c|}
\hline $\begin{array}{l}\text { S. } \\
\text { No. }\end{array}$ & $\begin{array}{l}\text { Name of the } \\
\text { elements }\end{array}$ & Symbol & $\begin{array}{l}\text { Detection } \\
\operatorname{limit}_{\mu \mathrm{g} / \mathrm{cm}^{2}} \text { in }\end{array}$ & $\begin{array}{l}\text { Indoor } \\
\text { platform } \\
\mu \mathrm{g} / \mathrm{cm}^{2}\end{array}$ & $\begin{array}{l}\text { Outdoor } \\
\text { platform } \\
\mu \mathrm{g} / \mathrm{cm}^{2}\end{array}$ & $\begin{array}{l}\text { OSHA } \\
\text { permissible } \\
\text { exposure } \\
\text { limit } \mu \mathrm{g} / \mathrm{cm}^{2}\end{array}$ \\
\hline 1 & Silicon & $\mathrm{Si}$ & 0.3531 & 34.6903 & 10.9224 & $\mathrm{NA}$ \\
\hline 2 & Phosphorus & $\mathrm{P}$ & 0.0093 & BDL & BDL & $\mathrm{NA}$ \\
\hline 3 & Sulphur & $\mathrm{S}$ & 0.0609 & 6.3082 & 2.0501 & $\mathrm{NA}$ \\
\hline 4 & Chlorine & $\mathrm{Cl}$ & 0.0216 & 4.2014 & 3.5892 & $\mathrm{NA}$ \\
\hline 5 & Potassium & $\mathrm{K}$ & 0.0024 & 5.0885 & 1.9202 & $\mathrm{NA}$ \\
\hline 6 & Calcium & $\mathrm{Ca}$ & 0.003 & 12.7726 & 4.5459 & $\mathrm{NA}$ \\
\hline 7 & Scandium & $\mathrm{Sc}$ & 0.0069 & $\mathrm{BDL}$ & BDL & NA \\
\hline 8 & Titanium & $\mathrm{Ti}$ & 0.0042 & 0.6902 & 0.2461 & $\mathrm{NA}$ \\
\hline 9 & Vanadium & $\mathrm{V}$ & 0.0012 & 0.0148 & 0.0078 & $\mathrm{NA}$ \\
\hline 10 & Chromium & $\mathrm{Cr}$ & 0.0021 & 0.1205 & 0.0501 & 1 \\
\hline 11 & Manganese & $\mathrm{Mn}$ & 0.006 & 0.3585 & 0.0762 & 0.2 \\
\hline 12 & Iron & $\mathrm{Fe}$ & 0.0081 & 24.5378 & 2.5765 & 1 \\
\hline 13 & Cobalt & Co & 0.0027 & 0.0466 & 0.0072 & 0.1 \\
\hline 14 & Nickel & $\mathrm{Ni}$ & 0.0027 & 0.0354 & 0.0261 & 0.1 \\
\hline 15 & Copper & $\mathrm{Cu}$ & 0.0036 & 0.7324 & 0.1499 & 1 \\
\hline 16 & Zinc & $\overline{Z n}$ & 0.006 & 1.0397 & 0.3734 & 5 \\
\hline 17 & Gallium & $\mathrm{Ga}$ & 0.015 & BDL & BDL & $\mathrm{NA}$ \\
\hline 18 & Germanium & $\mathrm{Ge}$ & 0.0084 & BDL & BDL & $\mathrm{NA}$ \\
\hline 19 & Arsenic & As & 0.0048 & 0.0159 & BDL & 0.01 \\
\hline 20 & Selinium & $\mathrm{Se}$ & 0.0096 & BDL & BDL & 0.2 \\
\hline 21 & Bromine & $\mathrm{Br}$ & 0.0048 & 0.2383 & 0.092 & $\mathrm{NA}$ \\
\hline 22 & Rubidium & $\mathrm{Rb}$ & 0.0018 & 0.0133 & BDL & $\mathrm{NA}$ \\
\hline 23 & Strontium & $\mathrm{Sr}$ & 0.0099 & 0.0656 & 0.0233 & $\mathrm{NA}$ \\
\hline 24 & Yttrium & $\mathrm{Y}$ & 0.0096 & BDL & BDL & $\mathrm{NA}$ \\
\hline 25 & Molybdenum & $\mathrm{Mo}$ & 0.0078 & 0.3475 & 0.0084 & 15 \\
\hline 26 & Rhodium & $\mathrm{Rh}$ & 0.0192 & $\mathrm{BDL}$ & BDL & $\mathrm{NA}$ \\
\hline 27 & Palladium & $\mathrm{Pd}$ & 0.0171 & $\overline{B D L}$ & BDL & $\mathrm{NA}$ \\
\hline 28 & Silver & $\mathrm{Ag}$ & 0.0132 & $\mathrm{BDL}$ & BDL & $\mathrm{NA}$ \\
\hline 29 & Cadmium & $\mathrm{Cd}$ & 0.0186 & 0.1339 & 0.0708 & 0.01 \\
\hline 30 & Indium & In & 0.0189 & 0.0244 & BDL & $\mathrm{NA}$ \\
\hline 31 & Tin & $\mathrm{Sn}$ & 0.0249 & 0.5077 & 0.03 & 2 \\
\hline 32 & Antimony & $\mathrm{Sb}$ & 0.0231 & 0.0917 & BDL & 0.5 \\
\hline 33 & Tellurium & $\mathrm{Te}$ & 0.0222 & BDL & BDL & $\mathrm{NA}$ \\
\hline 34 & Iodine & $\mathrm{I}$ & 0.0264 & 0.0265 & BDL & $\mathrm{NA}$ \\
\hline 35 & Caesium & Cs & 0.0375 & BDL & BDL & $\mathrm{NA}$ \\
\hline 36 & Barium & $\mathrm{Ba}$ & 0.0441 & 0.5052 & 0.146 & 0.5 \\
\hline 37 & Lanthanum & $\mathrm{La}$ & 0.0831 & BDL & BDL & $\mathrm{NA}$ \\
\hline 38 & Tungsten & $\mathrm{W}$ & 0.0387 & BDL & BDL & $\mathrm{NA}$ \\
\hline 39 & Gold & $\mathrm{Au}$ & 0.009 & $\mathrm{BDL}$ & BDL & NA \\
\hline 40 & Thallium & TI & 0.0063 & BDL & BDL & NA \\
\hline 41 & Lead & $\mathrm{Pb}$ & 0.0072 & 0.5303 & 0.2816 & 0.05 \\
\hline
\end{tabular}

BDL-Below detection level; NA-Not available 
Figure 3. Indoor/Outdoor Percentage Distribution of Metal Concentration

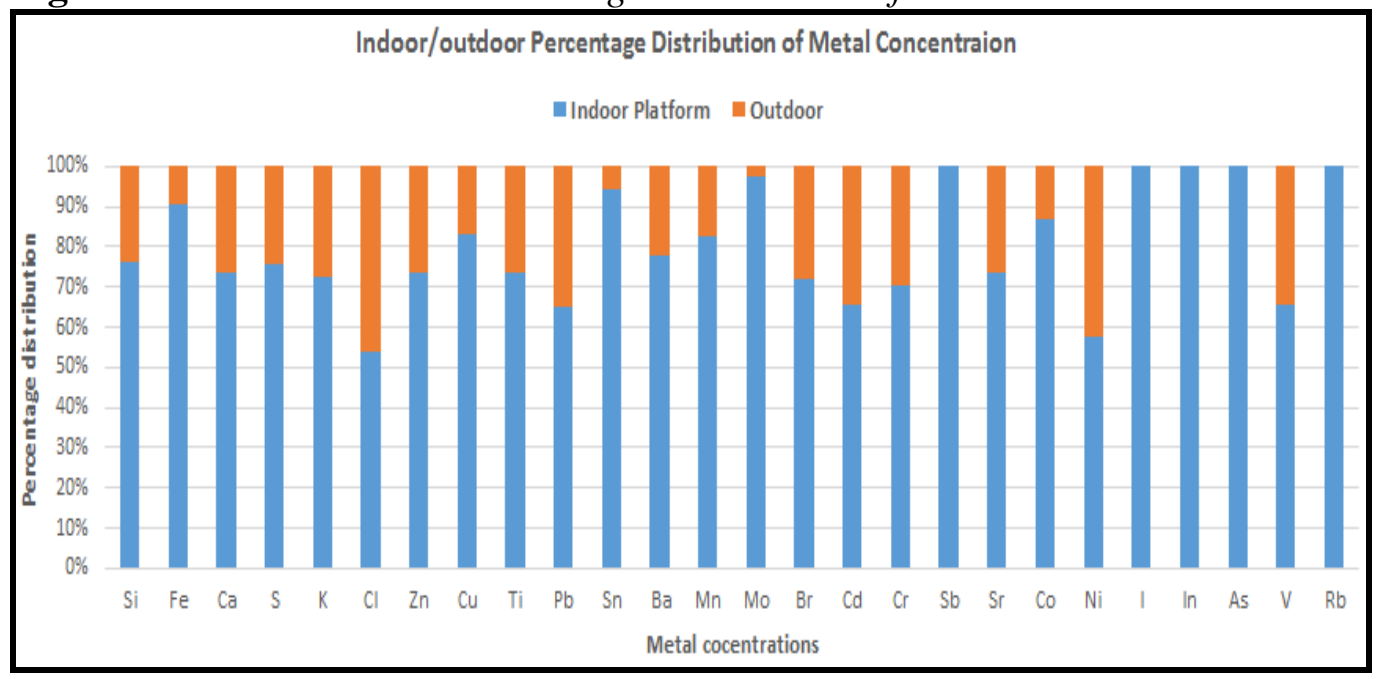

Out of the 41 metals analyzed from RSP, Fe was the second most abundant metal. Fe may have originated from wear of steel during the friction periods between wheels and rail, wear of brakes and the vaporization of metals due to sparking between the rail and wheel (Gutierrez et al., 2006). Further, Eom et al. (2013) have found that the Fe concentration is the most enriched metal in the underground metro systems, iron species in subway particles are of prime interest because of their different toxicity and magnetic properties according to the iron species (Eom et al., 2013). The concentration of Mn was less consistent. High levels of Mn were measured in some metro stations and the contribution from outside traffic is suspected (Awad, 2002), while other studies (Cheng et al., 2008; Okeson et al., 2004) reported the contribution of Mn from friction erosion of the metro rails. Furthermore, dust re-suspension was linked with passenger activities, effect of train piston effects (airflow at the front of the platform) and floor cleaning (Aarnio et al., 2005).

In this analysis, high mass concentration of $\mathrm{Fe}$ was found the most abundant element in the UMS platform, i.e. nearly 9.5 times higher than that measured in ambient RSP. Other scientific studies also confirmed that a high concentration of $\mathrm{Fe}$ has also been found in the London (Seaton et al., 2005; Vasconcellos, 2001), Mexico City (Mugica Alvarez et al., 2012) and Helsinki (Aarnio et al., 2005) subway particles. The Mn is likely to be produced from processes at rail wheel brake interfaces, because $\mathrm{Mn}$ is another component of rail steel (Li Guo et al., 2014). The crustal species such as K, Ca and Ti are mainly originated from soil (Kam et al., 2011). Furthermore, the re-suspension of particles was linked with commuters activities, piston effect (airflow at the front of the platform), and floor cleaning (Awad, 2002). Other important determinants of the increasing levels of exposure to RSP may also derive from improper maintenance ventilation systems in UMS (i.e. supply ducts), tunnels and train movements within UMS (Furuya et al., 2001). The indoor/outdoor percentage distribution of the elemental concentration also confirms that most of the elements are released within the UMS. Out of 41 elements, only 26 elements were plotted, others are BDL (Figure 3). 
Numerous scientific studies have found that the particles from the UMS are mainly from the rail wheel brake, particle re-suspensions due to internal activities and the infiltration of particles from outdoor environments (Jung et al., 2012; Querol et al., 2012).

The element concentrations measured in this study were compared with international regulations and guidelines and were found to be considerably lower than the limit values stipulated by the Occupational Safety and Health Administration (OSHA) regulations in the US (eg. As, Cr, Co, Cu, Pb, Ni and Mo). The accepted limit values for different metals recommended by OSHA for $\mathrm{As}=10 \mu \mathrm{g} / \mathrm{m} 3, \mathrm{Cr}=1 \mathrm{mg} / \mathrm{m} 3, \mathrm{Co}=0.1 \mathrm{mg} / \mathrm{m} 3, \mathrm{Cu}=1 \mathrm{mg} / \mathrm{m} 3, \mathrm{~Pb}=50$ $\mu \mathrm{g} / \mathrm{m} 3, \mathrm{Ni}=1 \mathrm{mg} / \mathrm{m} 3, \mathrm{Mo}=15 \mathrm{mg} / \mathrm{m} 3$ and the international guidelines (e.g., WHO Air Quality Guideline for $\mathrm{Pb}=500 \mathrm{ng} / \mathrm{m} 3$ and $\mathrm{Cd}=5 \mathrm{ng} / \mathrm{m} 3$ ) (Crump et al., 2000).

The evidence implicates that transition metals are mediators of inflammation and cytotoxicity via oxidative mechanisms. Ambient air particles contain ionizable metals that produce reactive oxygen species in aqueous solutions generating oxidative stress (Colombi et al., 2013). Soluble transition metals such as $\mathrm{Co}, \mathrm{Cu}, \mathrm{Fe}, \mathrm{Mn}, \mathrm{V}$ and $\mathrm{Zn}$ participate in various metabolic and signaling pathways and have been related with DNA damage and oxidative stress (Furuya et al., 2001; Kim et al., 2008).

\section{Conclusions}

This is the first comprehensive IAQ study in UMS in Delhi city, which could serve to build up a better understanding of the mass/chemical speciation and its negative health effects of RSP on commuters and workers in the UMS. The results of this present study show that the indoor elemental concentrations in UMS platform have a higher than the above ground level. Trace elements were found to be dominant in carcinogenic metals influencing the indoor RSP collected in UMS platform (i.e. $\mathrm{Zn}>\mathrm{Cu}>\mathrm{Mn}>\mathrm{Cd}>\mathrm{Cr}>\mathrm{Ni}$ ). Further, the present analysis provided a comprehensive assessment of RSP and its chemical characterization in selected UMS in Delhi city. In addition, this study may ultimately provide a unique database and systematic methodology for carrying out the IAQ study in the UMS. In India, the comprehensive IAQ study in the UMS is not done so far.

\section{Acknowledgments}

The authors would like to acknowledge the support of the Ministry of Environment and Forests (MoEF), the Governments of India, New Delhi, India, for funding this Ph.D. fellowship and we also express our thanks to the Central Pollution Control Board (CPCB), Delhi, India, for their EDXRF instrument facility to analyze the elemental compositions. Finally, the authors 
extend sincere thanks to DMRC, Delhi, India, for their help in permission and logistical facilities to carry out a sampling/monitoring campaign in the selected UMS.

\section{References}

Aarnio, P., Yli-Tuomi, T., Kousa, A., Makela, T., Hirsikko, A., Hameri, K., Raisanen, M., Hillamo, R., Koskentalo, T., Jantunen, M. The concentrations and composition of and exposure to fine particles (PM2.5) in the Helsinki subway system. Atmospheric Environment, 39, 5059-5066, 2005.DOI=http:// bit.ly/1RKhSbA.

Awad, A. H. A. Environmental Study in subway metro stations in Cairo, Egypt. Journal of Occupational Health, Vol. 44, pp. 112-118, 2002. DOI= http://ci.nii. ac.jp/naid/110003723205.

Boudia, N., Halley, R., Kennedy, G., Lambert, J., Gareau, L., Zayed, J. Manganese concentrations in the air of the Montreal (Canada) subway in relation to surface automobile traffic density. Science of the Total Environment, Vol. 366, pp. 143147, 2006. DOI= http://www.ncbi.nlm.nih.gov/pubmed/16297437.

Chan, L. Y., Lau, W. L., Zou, S. C., Cao, Z. X., Lai, S. C. Exposure level of carbon monoxide and respirable suspended particulate in public transport modes while commuting in urban area of Guangzhou, China, Atmospheric Environment, Vol. 36, pp. 5831-5840, 2002. DOI= http://bit.ly/1kIuQvw.

Cheng, Y. H., Lin, Y. L., Liu, C. C. Levels of PM10 and PM2.5 in Taipei Rapid Transit System. Atmospheric Environment, Vol. 42(31), pp. 7242-7249, 2008. DOI= http://bit.ly/1PzdLje.

Chillrud, S. N., Grass, D., Ross, J. M., Coulibaly, D., Slavkovich, V., Epstein, D., et al. Steel dust in the New York City subway system as a source of manganese, chromium, and iron exposures for transit workers. J. Urban Health, Vol. 82 (1), pp. 33-42, 2005. DOI= http://www.ncbi.nlm.nih.gov/pubmed/15738337.

Colombi C., Angius S., Gianelle V., Lazzarini M. Particulate matter concentrations, physical characteristics and elemental composition in the Milan underground transport system, Atmos Environ, Vol. 70, pp. 166-78, 2013. DOI= http://bit.ly/1HEgfXf.

Crump, K. S. Manganese exposure in Toronto during use of the gasoline additive methylcyclopentadienyl manganese tricarbonyl. Journal of Exposure Analysis and Environmental Epidemiology, Vol. 10, pp. 227-239, 2000. DOI=http://www.ncbi.nlm.nih.gov/pubmed/10910116.

Eom H. J., Jung H. J., Sobanska S., Chung S. G., Son Y. S., Kim J. C., et al. Iron speciation of airborne subway particles by the combined use of energy dispersive electron probe X-ray microanalysis and Raman micro spectrometry, Anal Chem; Vol. 85, pp. 10424-31, 2013. DOI= http://1.usa.gov/1HExp6Q.

Frampton, M. W., Ghio, A. J., Samet, J. M., Carson, J. L., Carter, J. D., Devlin, R. B. Effects of aqueous extracts of PM10 filters from the Utah Valley on human airway epithelial cells. American Journal of Physiolgy-Lung Cellular and Molecular Physiology, Vol. 21, pp. 960-967, 1999. DOI= http://1.usa.gov/ 1iQdKKR.

Furuya, K., Kudo, Y., Okinagua, K., Yamuki, M., Takahashi, K., Araki, Y., Hisamatsu, Y. Seasonal variation and their characterization of suspended 
particulate matter in the air of subway stations. Journal of Trace and Microprobe Techniques, 19 (4), 469-485, 2001. DOI= http://bit.ly/1WOjCSj.

Gutierrez, C. A. E., Roubicek, D. A., Cebrian, G. M. E., De Vizcaya, R. A., Sordo, C. M., Ostrosky, W. P. Effect of chemical composition on the induction of DNA damage by urban airborne particulate matter. Environmental and Molecular Mutagenesis, Vol. 47, pp. 199-211, 2006. DOI= http://www.ncbi.nlm.nih.gov/ pubmed/16355389.

Johansson, C., Johansson, P. A. Particulate matter in the underground of Stockholm. Atmospheric Environment, Vol. 37 (1), pp. 3-9, 2003. DOI= http://bit.ly/1WKe2 Wm.

Jung M. H., Kim H. R, Park Y. J., Park D. S., Chung K. H., Oh S. M. Genotoxic effects and oxidative stress induced by organic extracts of particulate matter (PM10) collected from a subway tunnel in Seoul, Korea, Mutat Res, Vol. 749, pp. 39-47, 2012. DOI= http://www.ncbi.nlm.nih.gov/pubmed/23350069.

Kam, W., Cheung, K., Daher, N., Sioutas, C. Particulate matter concentrations in underground and ground-level rail systems of the Los Angeles Metro. Atmos. Environ. Vol. 45 (8), pp. 1506-1516, 2011. DOI= http://bit.ly/1Nosmtc.

Kang, S., Hwang, H., Park, Y., Kim, H., Ro, C. U. Chemical compositions of subway particles in Seoul, Korea determined by a quantitative single particle analysis. Environmental Science and Technology, Vol. 42, pp. 9051-9057, 2008. DOI= http://pubs.acs.org/doi/abs/10.1021/es802267b.

Karlsson, H., Nilsson, L., and Moller, L. Subway particles are more genotoxic than street particles and induce oxidative stress in cultured human lung cells, Chemical Research in Toxicology, Vol. 18, pp. 19-23, 2005. DOI= http://www.ncbi. nlm.nih.gov/pubmed/15651844.

Kim, K. Y., Kim, Y. S., Roh, Y. M., Lee, C. M., and Kim, C. N. Spatial distribution of particulate matter $\left(\mathrm{PM}_{10}\right.$ and $\left.\mathrm{PM}_{2.5}\right)$ in Seoul Metropolitan Subway stations, Journal of Hazardous Materials, Vol. 154, pp. 440-443, 2008. DOI= http://www.ncbi.nlm.nih.gov/pubmed/18036738.

Lee K., Duckshin Park, Miseok Oh, Younghun Yoon, Eunyoung Park. Source identification of $\mathrm{PM}_{10}$ pollution in subway passenger cabins using positive matrix factorization, Atmospheric Environment, Vol. 49, pp. 180-185, 2012. DOI= http://bit.ly/1MlAGtT.

Li Guo, Yunjie Hu, Qingqing Hu, Jun Lin, Chunlin Li, Jianmin Chen, Lina Li, Hongbo Fu. Characteristics and chemical compositions of particulate matter collected at the selected metro stations of Shanghai, China, Science of the Total Environment, Vol. 496, pp. 443-452, 2014. DOI= http://www.ncbi.nlm.nih.gov/ pubmed/25105755.

Lu Senlin, Dingyu Liu, Wenchao Zhang, Pinwei Liu, Yi Fei, Yan Gua, Minghong Wu, Shang Yu, Shinich Yonemochi, Xiaoju Wang, Qingyue Wang. Physico-chemical characterization of PM2.5 in the microenvironment of Shanghai subway, Atmospheric Research, Vol. 153, pp. 543-552, 2015. DOI= http://bit.ly/ 1WOjZfG.

Mugica Alvarez, V., Figueroa Lara, J., Romero Romo, M., Sepulveda Sanchez, J., Lopez-Moreno, T. Concentrations and properties of airborne particles in the Mexico City subway system. Atmospheric Environment, 49, 284-293,2012.DOI= http://bit.ly/1M3s8d8.

Okeson, C. D., Riley, M., Riley-Saxton, E. In vitro alveolar cytotoxicity of soluble components of airborne particulate matter: effects of serum on toxicity of transition metals. Toxicology in Vitro, Vol. 18, pp. 673-680, 2004. DOI= http://www.ncbi.nlm.nih.gov/pubmed/15251186. 
Perrino, C., S. Tiwari, M. Catrambone, S.D. Torre, E. Rantica and S. Canepari. Chemical characterization of atmospheric PM in Delhi, India, during different periods of the year including Diwali festival. Atmos. Pollut. Res., Vol. 2(4), pp. 418-427, 2011. DOI= http://bit.ly/1L7IkX0.

Pfeiffer, G. D., Harrison, R. M., Lynam, D. R. Personal exposures to airborne metals in London taxi drivers and office workers in 1995 and 1996. The Science of the Total Environment, Vol. 235 (1-3), pp.253-260, 1996. DOI= http://bit.ly/ $1 \mathrm{HtaDV} 1$.

Querol X., Moreno T., Karanasiou A., Reche C., Alastuey A., Viana M., et al. Variability of levels and composition of PM10 and PM2.5 in the Barcelonametro system, Atmos ChemPhys, Vol. 12, pp. 5055-76, 2012. DOI= http://bit.ly/1M3s dh2.

Ripanucci, G., Grana, M., Vicentini, L., Magrini, A., and Bergamaschi, A. Dust in the underground railway tunnels of an Italian town, Journal of Occupational and Environmental Hygiene, Vol. 3, pp. 16-25, 2006. DOI= http://www.ncbi.nlm. nih.gov/pubmed/16482974.

Salma, I., Weidinger, T., and Maenhaut, W. Time-resolved mass concentration, composition and sources of aerosol particles in a metropolitan underground railway station, Atmos. Environ., Vol. 41, pp. 8391-8405, 2007. DOI= http://bit. ly/1WOkoi6.

Seaton, A., Cherrie, J., Dennekamp, M., Donalson, K., Hurley, F., and Tran, L. The London underground: dust and hazards to health, Occupational and Environmental Medicine, Vol. 62, 10, pp. 355-362, 2005. DOI= http://www.ncbi. nlm.nih.gov/pmc/articles/PMC1741036/.

Simge Taner, Beyhan Pekey, Hakan Pekey. Fine particulate matter in the indoor air of barbeque restaurants: Elemental compositions, sources and health risks, Science of The Total Environment, Vol. 454-455, pp. 79-87, 2013. DOI= http://bit.ly/ 1GUqT1c.

Sitzmann B., Kendall M., Watt J., Williams I. Characterization of airborne particles in London by computer-controlled scanning electron microscopy, Science of Total Environment, Vol. 241 (1-3), pp. 63-73, 1999. DOI= http://bit.ly/1O0V5XR.

U.S. Environmental Protection Agency, Compendium of Methods for the Determination of Inorganic Compounds in Ambient Air, Compendium Method IO-3.3, Determination of Metals in ambient Particulate Matter using X-ray Fluorescence (XRF) Spectroscopy, EPA/625/R-96/010a, Office of Research and Development, June 1999. DOI=www.epa.gov/ttnamti1/files/ambient/inorganic/ mthd-3-3.pdf

Vasconcellos, E. 2001. Urban transport, environment and equity: The case for developing countries. London, UK: Earthscan Press, 2001.

Zhang, W., Jiang, H., Dong, C., Yan, Q., Yu, L., Yu, Y. Magnetic and geochemical characterization of iron pollution in subway dusts in Shanghai, China. Geochem. Geophys. Geosyst. Vol. 12 (6), 2011. DOI= 10.1029/2011GC003524. 